\title{
FIZIOLOGINIO AFEKTO BŪSENOS REIKŠME் NUŽUDYMUI IR SUNKIAM SVEIKATOS SUTRIKDYMUI KVALIFIKUOTI
}

\author{
Rita Aliukoniené $\dot{1}^{1}$, Neringa Aliukonien $\dot{e}^{2}$, Vygintas Aliukonis ${ }^{3}$ \\ ${ }^{1}$ Vilniaus universiteto Teisès fakultetas, ${ }^{2}$ Vilniaus universiteto Medicinos fakultetas, \\ ${ }^{3}$ Vilniaus universiteto Medicinos fakultetas, Lietuvos bioetikos komitetas
}

\begin{abstract}
Raktažodžiai: nužudymas, sunkus sveikatos sutrikdymas, neteisètas ar itin ižeidžiantis nukentejusiojo asmens poelgis, patologinis ir fiziologinis afektas, teismo psichiatrinè ekspertizè.
\end{abstract}

\section{Santrauka}

Lietuvos ir visų demokratinių valstybių teisèje žmogaus gyvybe bei jo sveikata yra laikomos svarbiausiomis vertybemis, kurios unikalios tuo, kad yra visų kitų žmogaus vertybių sąlyga ir pagrindas. Žmogaus gyvybė ir sveikatos apsauga gali būti užtikrinama priimant ịvairių teisès šakų normas, taip pat nustatant baudžiamają atsakomybę už kèsinimąsi ị žmogaus gyvybę ir sveikatą. Lietuvos Respublikos baudžiamajame kodekse (toliau - BK) atsakomybé už paprastą ir kvalifikuotą nužudymą numatyta 129 straipsnyje, o už sunkų sveikatos sutrikdymą - 135 straipsnyje. Be to, šios nusikalstamos veikos gali būti padaromos kaltininkui esant riboto pakaltinamumo būsenoje (fiziologinis afektas), todèl įstatymų leidejjas tokias veikas laiko privilegijuotomis ir įtvirtina atsakomybę už nužudymą ir sunkų sveikatos sutrikdymą labai susijaudinus atskirose kodekso normose (BK 130 str. ir 136 str.).

Nužudymo ir sunkaus sveikatos sutrikdymo afekto būsenoje kvalifikavimo ir atribojimo klausimai yra pakankamai sudètingi praktiniu aspektu ne tik teisininkams, bet ir teismo psichiatrams, nes dažniausiai tiriamojo asmens psichikos būsena nusikalstamos veikos metu yra ištiriama žymiai vẻliau, t. y. ekspertai turi duoti išvadą apie tiriamojo subjekto psichikos būseną praeityje.

Šio tiriamojo darbo metu atlikta 20 baudžiamųjų bylų medžiagos analizè leidžia padaryti išvadą, jog tik pavieniais atvejais konstatuojama, kad kaltininkas padarė nužudymą ar sunkų sveikatos sutrikdymą fiziologinio afekto sukeltoje būsenoje. Daž- niausiai analizuojamas nusikalstamas veikas padaro pakaltinami subjektai, o žymiai rečiau - psichikos ligoniai, t. y. nepakaltinami asmenys.

\section{Ivadas}

Nekyla abejonių, kad esminių žmogaus teisių - teisès ị gyvybę, sveikatą - apsauga ... „yra tapusi didžiosios dalies demokratinio pasaulio valstybių, taip pat ir Lietuvos, konstitucinès kontrolès objektu“[6]. Teisę i žmogaus gyvybès ir sveikatos apsaugą užtikrina Lietuvos Respublikos Konstitucija ir kiti nacionaliniai teisès aktai $[1,3,4]$. Suprantama, kad kiekviena valstybè, saugodama prigimtinę žmogaus teisę i gyvybę ir sveikatą, imasi ịvairių apsaugos priemonių, tačiau viena iš svarbiausių - baudžiamieji ịstatymai, reglamentuojantys atsakomybę už neteisètą kito asmens gyvybės atėmimą arba žmogaus sveikatos sutrikdymą. Nusikalstamomis veikomis žmogaus gyvybei ir sveikatai yra kèsinamasi ị reikšmingiausias vertybes, todèl ịstatymų leidejjas tokias veikas priskiria prie labiausiai pavojingų reiškinių. Jau pačioje žmogaus gyvenimo pradžioje valstybė, siekdama, kad žmogus taptų pilnaverčiu visuomenès nariu, privalo užtikrinti jo galimybę igyvendinti konstitucinę teisę ị gyvybę ir sveikatą, todėl nusikalstamų veikų žmogaus gyvybei ir sveikatai tyrimai - nuolatinis aktualumo neprarandantis reiškinys.

Lietuvos Respublikos baudžiamasis kodeksas saugo ir gina kiekvieno žmogaus teisę ị gyvybę, kaip visų kitų teisių pagrindą [2]. Ši nuostata galioja ir sveikatai, kuri ne mažiau svarbi už gyvybę, kadangi tik sveikas, darbingas žmogus gali save visapusiškai realizuoti gyvenime. Neabejotina, kad viena iš baudžiamuju įstatymų pagrindinių paskirčių yra žmogaus, jo vertybių ir interesu apsauga, o nusikalstamos veikos žmogui yra ypatingos tuo, kad jomis kèsinamasi ị žmogų, kaip gamtos kūrinị, jo pagrindines, igimtas vertybes [7].

Nuo 2003 m. gegužès 1 d. Lietuvoje ịsigaliojo naujasis baudžiamasis kodeksas, nustatantis šiuolaikinę vertybių ir 
prioritetų sistemą, todèl nenuostabu, kad jo normų taikymas kelia probleminių klausimų tiek teoriniu, tiek ir praktiniu aspektu. Pažymètina, kad naujajame baudžiamajame istatyme numatyta atsakomybė už dvi nusikalstamas veikas - nužudymą labai susijaudinus (BK 130 str.) ir sunkų sveikatos sutrikdymą labai susijaudinus (BK 136 str.), kurios laikomos privilegijuotomis dèl specialaus nusikalstamos veikos sudėties subjekto požymio - kaltininko būsenos (didelio susijaudinimo), kuris lèmè nusikalstamos veikos padarymą. Atkreiptinas demesys ir ị tai, kad tiek nužudymo, tiek ir sunkaus sveikatos sutrikdymo labai susijaudinus objektyvieji požymiai yra tokie patys kaip nužudymo, numatyto BK 129 str. 1 d., ir sunkaus sveikatos sutrikdymo, numatyto BK 135 str. 1 d. Baudžiamosios teisès doktrinoje nužudymą ir sunkų sveikatos sutrikdymą labai susijaudinus iprasta vadinti nužudymu ar sunkiu sveikatos sutrikdymu afekto būklejje. Akcentuotina ir tai, kad BK numatytas sunkus sveikatos sutrikdymas labai susijaudinus yra vienintelè sunkaus sveikatos sutrikdymo sudetis, kurią įstatymų leidèjas sieja tik su nukentėjusiojo sužalojimu, nes BK 136 str. nèra numatytas žmogaus susargdinimas labai susijaudinus. Pabrèžtina, kad nužudymo ir sunkaus sveikatos sutrikdymo sudètys laikomos privilegijuotomis dèl subjekto ypatingos būsenos (fiziologinio afekto), t. y. riboto kaltininko pakaltinamumo ir BK 130 str., 136 str. dispozicijose numatytu sąlygų.

Be to, šiose nusikalstamų veikų sudètyse nukentejusiojo vaidmuo, skirtingai nei kituose nusikaltimuose žmogaus gyvybei ir sveikatai, taip pat yra ypatingas, nes būtent neteisèti arba amoralūs ir ịžeidžiantys nukentejusiojo veiksmai sukelia kaltininkui fiziologinio afekto būklę, lemiančią tyčios (dažniausiai netiesioginès) atsiradimą nužudyti ar sunkiai sužaloti nukentėjusịjị.

Darbo tikslas - atsižvelgiant $\mathfrak{i}$ šiuolaikines psichiatrijos, psichologijos ir baudžiamosios teisès, mokslų koncepcijas bei teismų praktiką, ištirti nužudymo ir sunkaus sveikatos sutrikdymo medicininius bei teisinius kriterijus, išanalizuoti žmogaus didelio susijaudinimo būsenos sampratą (fiziologinį afektą) ir aptarti sąlygas, kurioms esant, kaltininko veika kvalifikuojama pagal BK 130 arba 136 straipsnius.

\section{Darbo objektas ir metodai}

Straipsnyje nagrinejjama ypatinga nusikalstamą veiką padariusio asmens psichine būsena kaip vienas iš kriterijų, pagal kuri atskiriamas privilegijuotas nužudymas ar sunkus sveikatos sutrikdymas nuo pagrindinès ar kvalifikuotos tokios nusikalstamos veikos sudèties. Tyrimo metu buvo išanalizuota Lietuvos teismuose išnagrinètų 20-ies baudžiamujų bylų ir jose esančių psichiatrinių ekspertizių medžiaga bei padarytos atitinkamos išvados, išstudijuota ir apibendrinta šiam tyrimui aktuali medicininè, psichologinè ir teisinè literatūra. Atliekant tyrimą, naudoti lingvistinis, gramatinis, sisteminis, lyginamasis, aprašomosios statistikos ir loginès analizès metodai.

\section{Tyrimo rezultatai ir diskusija}

Būtų netiesa, jeigu pasakytume, kad žmogus nugyvena savo gyvenimą nepatirdamas konfliktinių situacijų, t. y. konflikto su pačiu savimi, aplinkiniais ir kt. Psichopatologijos požiūriu būna dviejų tipų konfliktinès situacijos arba reakcijos - keliančios grèsmę arba jos nekeliančios. Grèsmès nekeliantys konfliktai yra visai nesvarbūs, kadangi jie nèra patogeniški. Grèsmę keliančio tipo konfliktai yra reikšmingi, nes labai dažnai jie yra patogeniški. Negana to, net ir tariamai grèsmę kelianti situacija konkrečiam individui gali sukelti psichologinès grèsmès jausmą, pasireiškianti pačiomis ịvairiausiomis emocijomis [5]. Neabejotina, kad emocijos ir jausmai yra žmogaus santykio su savimi ir aplinka išgyvenimai, kuriuos sukelia tam tikrų žmogaus poreikių patenkinimas arba nepatenkinimas. Taigi emocijos (lot. emoveo - jaudinti, dirginti) yra ypatinga žmogaus psichinių procesų arba būsenų rūšis. Jos pasireiškia visą žmogaus gyvenimą, patiriant kokias nors reikšmingas gyvenimiškas situacijas (džiaugsmą, pyktị, ìtūži, baimę), reiškinius ir ịvykius. Emocijos yra vienas iš pagrindinių psichinio gyvenimo reguliatorių ir atsiranda bet kokioje žmogaus veikloje. Emocijomis arba emociniais išgyvenimais dažniausiai vadinamos pačios îvairiausios žmogaus reakcijos: nuo audringų iki subtilių nuotaikos atspalvių. Emocijos gali būti ịvairių rūšių: teigiamos ir neigiamos, tačiau pažymètina, kad stresinèje situacijoje gali pasireikšti afekto būklè, kuri yra ypatinga emocinių reiškinių rūšis, besiskirianti nuo paprastų emocijų didele jèga ir trumpu veikimu. Ištikus afekto būklei, sustabdomos visos kitos psichinès reakcijos. Dažniausiai afekto būklè ištinka sudètingu ar kritiniu žmogaus gyvenimo momentu. Moksliniuose žodynuose afektas (lot. affectus - susijaudinimas) dažniausiai apibrèžiamas kaip stiprus susijaudinimas, jausmų (dažniausiai neigiamų) protrūkis, kurị sukelia staiga pasikeitusios gyvenimo aplinkybės [20,10]. Taigi afektą galima apibūdinti kaip tokią būseną, kurios metu žmogui dèl staigaus ir labai didelio susijaudinimo, pasireiškiančio stipriu ir giliu pergyvenimu, dalinai aptemsta sąmoné, susilpnejja jo savitvarda, t. y. gebejjimas kontroliuoti ir valdyti savo elgesị, todèl jis gali padaryti tai, ko nepadarytų būdamas normalioje būklëje.

Atsižvelgiant ị tai, kad žmogaus sveikata yra medicininẻ kategorija, apibrèžiama kaip fizinis ir dvasinis individo normalumas, atskleidžiant psichikos sutrikimų sampratą, 


\section{4}

verta vadovautis medicinine literatūra [9]. Psichiatrijos moksle skiriamos dvi afekto rūšys: patologinis ir fiziologinis. Patologinis afektas - tai tam tikra būsena, kurios metu sutrinka žmogaus sąmonè, o jo veiką nulemia emocijos, dèl kurių jis nesugeba įvertinti situacijos ir savo elgesio padarinių. Pavyzdžiui, viena iš dažniausiai psichiatrų praktikoje sutinkamų patologinių būklių, kuriai būdingos atsirandančios regos, klausos ir kitokios haliucinacijos, yra psichozé, kuriai praejjus, patirtų psichofizinių išgyvenimų žmogus dažnai neprisimena, arba juos suvokia fragmentiškai, kaip sapną [17,21]. Kitaip tariant, sunkios žmogaus psichikos anomalijos taip iškreipia psichikos funkcionavimą, kad žmogus nesugeba adekvačiai ir realiai suvokti savo išorinès aplinkos, o tuo pačiu ir sąmoningai valdyti ir kontroliuoti savo elgesio. Pavyzdžiui, Vilniaus apygardos teismas 2014 m. spalio 17 d. nutartyje nurode, kad V. Š., būdamas nepakaltinamumo būsenos, savo namuose, veikdamas itin žiauriai abiejose rankose laikomais peiliais sudavė savo žmonai 76 smūgius ị ịvairias kūno vietas. Nuo patirtų sužalojimų ir gausaus nukraujavimo nukentejusioji mirè. Teismo psichiatrijos - teismo psichologijos ekspertizès akto išvadoje nurodoma, kad V. Š. inkriminuojamos veikos padarymo metu nustatyti ūminiai psichoziniai sutrikimai, vyraujant kliedesiams, su susijusiu ūminiu stresu, dèl kurių jis negalëjo suprasti savo veiksmų esmés ir jų valdyti [33].

Taigi, patologinis afektas yra nepakaltinamumo pagrindas, nes patologinis afektas reiškia, kad dèl didelio susijaudinimo žmogus nesuvokia savo daromų veiksmų prasmés arba negali kontroliuoti savo elgesio, todèl yra nepakaltinamas ir už savo veiksmus, padarytus patologinio afekto būsenoje, neatsako [32,34,35,37]. Kita vertus, atkreiptinas dèmesys, jog kai kurie medicinos mokslo atstovai pažymi, kad psichiatrinis nepakaltinamumo kriterijus tèra prielaida pripažinti asmenį nepakaltinamą, nes ne kiekvienu atveju psichikos sutrikimas sukelia tokią būseną, dèl kurios asmuo negali suprasti savo veiksmų arba jų valdyti nusikalstamos veikos padarymo metu [12].

Kita afekto rūšis yra fiziologinis afektas, kuris nepašalina nepakaltinamumo ir dažniausiai apibrèžiamas kaip labai stipri žmogaus emocinè reakcija ị kokị nors dirgiklį, dažniausiai neigiamą (įskaudinimas, įžeidimas, pasityčiojimas), kuriai būdingas pergyvenimų stiprumas, difuzinis poveikis psichikai, ūmi išorinè išraiška $[18,14]$. Manytina, kad fiziologinis afektas yra viena iš galingiausių emocinių išraiškų, kurio išskirtiniais bruožais laikomi jo situatyvumas, t. y. situacija, kurioje jis kyla, didelis intensyvumas ir labai trumpa trukmè. Fiziologinio afekto metu staigiai keičiasi žmogaus dėmesys, mažèja jo perjungimas ir suvokimo lauke užsilaiko tik tie objektai, kurie dèl išgyvenimo pateko ị kompleksą. Be to, sutrinka žmogaus demesio kon- centracija, keičiasi mąstymas, jam būna sunku susikaupti ir numatyti savo veiksmų rezultatus. Medicininiai - klinikiniai šio reiškinio kriterijai galètų būti organinis galvos smegenų pažeidimas esant emocijų, valios sutrikimams, nežymiam intelektinių funkcijų susilpnèjimui, igimtas lengvo ar vidutinio laipsnio protinis atsilikimas ir kt. Kita vertus, kai kurių psichiatrijos mokslininkų nuomone, fiziologinis afektas mediciniškai visai neturi nieko bendra su psichikos sutrikimais ar ribotu pakaltinamumu, o tèra konkretaus žmogaus psichologinė reakcija ị stresą [16]. Tačiau pažymètina, jog psichiatrijos mokslo atstovai pripažįsta, kad nors fiziologinio afekto būsenoje esantis žmogus būna labai susijaudinęs, nepaisant tokio ryškaus emocinio susijaudinimo, jis supranta ir gali teisingai vertinti situaciją ir sugeba save valdyti [13].

Analizuojant nužudymą ir sunkų sveikatos sutrikdymą labai susijaudinus, kalbama būtent apie fiziologinị afektą, kurio metu žmogaus gebejjimas suvokti savo veiksmų prasmę ir juos valdyti yra labai sumažejęs, todèl kaltininko padaryta nusikalstama veika gali būti pripažinta privilegijuota. Pastebėtina, kad dèl medicininès fiziologinio afekto sampratos ir pagrindinių požymių, apibūdinančių fiziologinị afektą, diskutuojama ne tik medicininèje, psichologinèje, bet ir teisinejje literatūroje [8]. Kai kurie baudžiamosios teisès atstovai trumpai apibrèžia afekto esmę, teikdami, kad afektas - tai pergyvenimas, apsunkinantis žmogaus protinès funkcijos kontrolę [11]. Kiti teisininkai fiziologinio afekto sąvoką apibūdina žymiai plačiau, nurodydami būdingų fiziologiniam afektui požymių visumą ir teigdami kad pagal: 1) turinị afektas - psichinè būsena, pasireiškianti emocijomis; 2) dinamikos laipsni - stipri ir audringa sukelto tipo emocija; 3) poveikio psichikai laipsni - emocija, valdanti psichiką bei dezorganizuojanti psichini gyvenimą; 4) laiko tèkmę - trumpalaikè emocija; 5) kilmę - psichinè funkcija, labiausiai susijusi su intensyvia veikla [19]. Mūsų nuomone, dideliu susijaudinimu turètų būti pripažistamas toks žmogaus emocinès būklès pasikeitimas, dèl kurio staiga pakinta intelektualinè bei valinè kaltininko būsena ir susilpnejja jo veiksmų savikontrolè. Tačiau teismų praktikos analizè rodo, kad dažniausiai konstatuojama, jog kaltininko būsena nusikalstamos veikos padarymo metu neatitinka fiziologinio afekto būklès [23,24,26-29].

Pažymètina, kad fiziologinio afekto būsena, kai dèl didelio susijaudinimo žmogaus gebėjimas valdytis yra sumažejęs, tačiau jis suvokia savo veikos pobūdị ir turi nors ir sumažèjusią galimybę susivaldyti, švelnina atsakomybę ne visais nužudymo ar sunkaus sveikatos sutrikdymo atvejais, o tik esant BK 130 str. ir 136 str. numatytoms sąlygoms: 1) susijaudinimą neteisètais savo veiksmais - smurtu (fiziniu, psichiniu) ar sunkiu įžeidimu turi sukelti pats nukentejusy- 
sis; 2) susijaudinta turi būti staiga; 3 ) susijaudinta turi būti labai. Minètų sąlygų numatymas baudžiamajame ịstatyme leidžia teigti, kad norint kvalifikuoti veiką pagal BK 130 str. ir 136 str., būtina nustatyti: 1) objektyvias aplinkybes, buvusias iki nužudymo ar sunkaus sveikatos sutrikdymo padarymo, t.y. neteisètą ar amoralų nukentejusiojo elgesi kaltininko ar jam artimų asmenų atžvilgiu; 2) kaltininko buvimą fiziologinio afekto būsenoje nusikalstamos veikos padarymo metu; 3) sąryši tarp nukentejusiojo poelgio ir nusikalstamos veikos padarymo, t. y. faktą, kad būtent nukentejjusiojo elgesys nulėmè kaltininko atsakomają reakciją i nukentejusiojo veiksmus.

Būtina pastebėti, kad baudžiamosios teisès doktrinoje ir teismų praktikoje neteisètu poelgiu pripažistamas bet koks prieš kaltininką ar jam artimą asmenį nukreiptas nukentèjusiojo elgesys, galintis pasireikšti kèsinimusi į žmogaus gyvybę, sveikatą, turtą, ji mušant, kankinant, atimant laisvę ir kitaip fiziškai smurtaujant, taip pat ir psichiniu poveikiu t. y. grasinant pavartoti fizini smurtą, tyčiojantis, bauginant ir pan. Pavyzdžiui, Vilniaus apygardos teismas pripažino M. S. kalta pagal BK 130 str. už tai, kad virtuvėje, konflikto su A. K. metu, jam panaudojus prieš ją smurtą, t. y. sudavus smūgius ị veidą, spyrus ị koją, tampant už plaukų, ir dèl tokių neteisètų nukentejjusiojo veiksmų staiga labai susijaudinus, M. S. sudavè du smūgius peiliu į A. K. krūtinès sritị, dẻl kurių nukentejusysis įvykio vietoje mirè. Prokurorui ši nuosprendi apskundus apeliacinès instancijos skundui, jis buvo pakeistas ir M. S. veika perkvalifikuota ị BK 129 str. 1 d., iš esmès remiantis specialisto (eksperto psichiatro) išvada, kad nusikalstamos veikos padarymo metu M. S. nebuvo fiziologinio afekto būsenoje, nes ją eliminavo alkoholinis apsvaigimas [30].

Atkreiptinas dėmesys, kad itin ịžeidžiančio poelgio sąvoka yra vertinamojo pobūdžio, nes baudžiamajame ịstatyme neapibrěžta, todèl paliekama teismo diskrecijai. Pavyzdžiui, tiek pirmosios, tiek ir apeliacinès instancijos teismai nusprendè, kad T. V. padarè privilegijuotą nužudymą, numatytą BK 130 str., kadangi užèjęs ị kambarị pamatė stovintị su nuleistomis kelnemis ir apnuogintu lytiniu organu R. R. bei ant sofos gulinčią savo sugyventinę J. U., kurios krūtine buvo apnuoginta, todèl pagalvojo, kad R. R. lytiškai santykiavo su jo sugyventine. Paèmęs ant stalo gulejjusi peili, T. V. sudavè juo vieną smūgị i R. R. kairị žastą, o kitą - ị kairę krūtinès pusę, padarydamas kiauryminị širdies sužalojimą, dèl kurio R. R. įvykio vietoje mirè. Teismai pripažino, kad T. V. nužude R. R. staiga labai susijaudinęs dèl neteisèto ir ịžeidžiančio jị ir jo artimą asmenį - sugyventinę J. U. - nukentejjusiojo poelgio $[36,25]$.

Dažniausiai teismų praktikoje itin įžeidžiančiu poelgiu vertinami žmogaus garbès ir orumo pažeminimas veiksmu ar žodžiu, jo fizinių ar intelektinių trūkumų apibūdinimas vulgaria forma, tyčiojimasis ir pan. Baudžiamosios teisès doktrinoje vyksta nevienareikšmè diskusija dèl įžeidžiančio poelgio pasireiškimo formos. Vieni autoriai mano, kad nukentejusiojo veiksmai ar žodžiai, išreikšti nepadoria (vulgaria) forma, turètų būti vertinami dideliu įžeidimu, kiti tokiai nuomonei pritaria tik iš dalies, teigdami, jog nepadoria forma išreikštas neigiamas požiūris i asmeni, visada pažemina jo garbę ir orumą pačiu skausmingiausiu būdu, tačiau, ju nuomone, svarbiausia yra ne poelgio išraiškos forma (padori ar nepadori), o tai, kad įžeidžiantis nukentejusiojo poelgis, skirtas kaltininkui ar jam artimam asmeniui, sukèlè fiziologinio afekto būseną kaltininkui [8].

Privilegijuoto nužudymo ir sunkaus sveikatos sutrikdymo kvalifikavimui labai svarbi laiko trukme, t. y. nustatymas, kad nuo kaltininko susijaudinimo momento ir jo veiksmų turi būti praejjęs minimalus laiko tarpas, t. y. kaltininko atsakomieji veiksmai turi sekti iš karto po neteisètų ar įžeidžiančių nukentėjusiojo veiksmų, kadangi afektinè tyčia yra trumpalaikè. Pabréžtina, kad laiko trukmès klausimas nuo neteisèto ar įžeidžiančio nukentejusiojo poelgio iki nužudymo ar sunkaus sveikatos sutrikdymo padarymo, kuri turejjo ịtakos kaltininko afektinès tyčios išnykimui, yra vertinamoji kategorija, paliekama teismo diskrecijai. Pavyzdžiui, E. B. buvo nuteistas pagal BK 129 str. 2 d. 2 p., 3 p., 6 p. už tai, kad būdamas apsvaigęs nuo alkoholio, asmeninio konflikto su savo neigaliu tèvu metu, tyčia sudavè pastarajam 29 smūgius ị krūtinès sritị, dèl to nukentèjusysis mirè. Apeliaciniu skundu nuteistasis E. B. prašè jo veiką perkvalifikuoti ị BK 130 str., nurodydamas, jog tèvą nužudè dèl didelio ir staigaus susijaudinimo, kurị veikè ižžeidžiantis tèvo elgesys, nes grižęs ị namus, jis rado išdaužytus indus, tevas buvo nusiplèšęs sauskelnes, išmatomis ištepęs sieną prie lovos, rèkè ant nuteistojo, kuris dèl tokio įžeidžiančio tèvo elgesio labai susijaudino ir sudave jam smūgius, sukèlusius mirti.

Atmesdamas nuteistojo skundą, teismas nurodè, kad toks nukentejusiojo elgesys iš tikrujų buvo netinkamas ir jžeidžiantis, tačiau jis nebuvo nuteistajam staigus ir netikètas (nukentejjusysis taip elgdavosi ir anksčiau), galejjęs sukelti jam toki susijaudinimą, kuris iš dalies aptemdè nuteistojo sąmonę ir turèjo ịtakos suduoti 29 smūgius ị tẻvo krūtinės sriti. Teismas pažymėjo, jog byloje surinkti duomenys leidžia daryti išvadą, kad nors nuteistojo tyčia nužudyti tèvą susiformavo staiga, tačiau ne dèl didelio susijaudinimo (fiziologinio afekto), bet iš pykčio, kurị sukẻlè nuteistojo atlikti veiksmai [31].

Teismų praktikos analizè leidžia teigti, kad kvalifikuojant veikas, ypač reikšmingos teismo ekspertizès išvados, kuriomis patvirtinamas arba paneigiamas asmens buvimas 
afekto būsenoje [22]. Baudžiamosiose bylose dèl nužudymo ar sunkaus sveikatos sutrikdymo labai susijaudinus, priklausomai nuo teismo ekspertams iškeltų uždavinių, gali būti skiriama teismo psichiatrinè ar teismo psichologinè ekspertizè. Teismo psichiatrinè ekspertizè skiriama tais atvejais, kai iškyla abejonių dèl įtariamuju ar kaltinamujų psichinès sveikatos ir jų pakaltinamumo kriminalinès veikos padarymo metu, o teismo psichologinè ekspertizè - siekiant nustatyti individualius psichologinius tiriamojo ypatumus ar būseną, galejjusią turèti ịtakos jo elgesiui, pvz., fiziologini afektą. Tačiau baudžiamujjų bylų analizè rodo, kad dažniausiai tik kompleksinis asmens psichinès sveikatos ir jo individualiu psichologiniu ypatumų tyrimas išsamiai ir visapusiškai atsako ị visus klausimus, todèl paprastai baudžiamosiose bylose dèl nužudymo ar sunkaus sveikatos sutrikdymo labai susijaudinus skiriama kompleksinè teismo psichiatrinè - psichologinè ekspertizé, kurios metu kompleksiškai nustatomi tiriamojo psichikos sutrikimai, psichologiniai ypatumai ir somatoneurologiniai sutrikimai, galintys turèti reikšmės teisingam ir pagrịstam kriminalinès veikos kvalifikavimui.

Kita vertus, kai kurie baudžiamosios teisès mokslininkai pastebi tendenciją, kad teismai priima sprendimus vadovaudamiesi išimtinai teismo psichiatrijos ekspertizès išvadomis, nuosprendžio ar nutarties aprašomojoje dalyje atsisakymą taikyti ribotą pakaltinamumą pagrịsdami vien tik teismo psichiatrinès ekspertizès išvadomis, ir nenurodydami kitų ịrodymų, motyvų bei argumentų. Todèl daroma prielaida, kad teismai, išimtinai pasikliaudami ekspertizès išvadomis, dali savo kompetencijos perduoda teismo ekspertams, kuriems įstatymas tokių ịgaliojimų nenumato [15].

\section{Išvados}

1. Afektas - tai būsena, kurios metu žmogui dèl staigaus ir labai didelio susijaudinimo, pasireiškiančio stipriu ir giliu pergyvenimu, dalinai aptemsta sąmonè, susilpnejja jo savitvarda, t. y. gebejjimas kontroliuoti ir valdyti savo elgesị, todèl jis gali padaryti tai, ko nepadarytų būdamas normalioje būklèje.

2. Patologinis afektas yra nepakaltinamumo pagrindas, nes jo metu dèl didelio susijaudinimo žmogus nesuvokia savo daromų veiksmų prasmès arba negali kontroliuoti savo elgesio, todėl yra nepakaltinamas ir už savo veiksmus, padarytus patologinio afekto būsenoje, neatsako.

3. Fiziologinis afektas - tai labai stipri žmogaus emocinè reakcija ị kokị nors dirgiklį, dažniausiai neigiamą (įskaudinimas, įžeidimas, pasityčiojimas), kuriam būdingas pergyvenimų stiprumas, difuzinis poveikis psichikai, ūmi išorinè išraiška. Nepaisant tokio ryškaus žmogaus emocinio susijaudinimo, jis supranta ir gali teisingai vertinti situaciją ir sugeba save valdyti.

4. Fiziologinio afekto būsena švelnina atsakomybę ne visais nužudymo ar sunkaus sveikatos sutrikdymo atvejais, o tik esant BK 130 str. ir 136 str. numatytoms sąlygoms: 1) susijaudinimą neteisètais savo veiksmais - smurtu (fiziniu, psichiniu) ar sunkiu įžeidimu turi sukelti pats nukentejusysis; 2) susijaudinta turi būti staiga; 3 ) susijaudinta turi būti labai.

5. Privilegijuoto nužudymo ir sunkaus sveikatos sutrikdymo kvalifikavimui ypač svarbi laiko trukmè - nustatymas, kad nuo asmens susijaudinimo momento ir jo nusikalstamų veiksmų padarymo turi būti praèjęs minimalus laiko tarpas, t. y. kaltininko atsakomieji veiksmai turi sekti iš karto po neteisètų ar įžeidžiančių nukentejusiojo veiksmų, nes afektinè tyčia yra trumpalaikè.

6. Sunkus sveikatos sutrikdymas labai susijaudinus yra vienintelè sunkaus sveikatos sutrikdymo sudètis, kurią ịstatymų leidejjas sieja tik su nukentejusiojo sužalojimu, nes BK 136 str. nėra numatytas žmogaus susargdinimas labai susijaudinus.

\section{Literatūra}

1. Lietuvos Respublikos Konstitucija. Valstybės žinios, 1992; 33-1014.

2. Lietuvos Respublikos sveikatos sistemos ịstatymas. Valstybès žinios, 1994; 63-1231.

3. Lietuvos Respublikos psichikos sveikatos priežiūros ịstatymas. Valstybės žinios, 1995; 53-1290.

4. Lietuvos Respublikos baudžiamasis kodeksas. Valstybės žinios, 2000; 26-1968.

5. Abram H., Maslow. Motyvacija ir asmenybè. Vilnius, 2009; 144-145.

6. Abramavičius A., Baranskaitė A., Milinis A. Probleminiai žmogaus gyvybès pradžios ir pabaigos klausimo aspektai nužudymo kontekste. Jurisprudencija, 2011; 18(3): 1123.

7. Aliukonienė R. Veika kaip vienas iš sunkaus sveikatos sutrikdymo objektyviujų požymių. Teisè, 2013; 87:117.

8. Aliukonienè R. Sunkaus sveikatos sutrikdymas labai susijaudinus (Baudžiamojo kodekso 136 straipsnis) požymiai. Lietuvos Respublikos Baudžiamajam kodeksui 10 metų. Vilnius, 2011; 304-305, 309-310.

9. Aliukonienė R., Jasulaitis A., Aliukonis V., Maciulytė N. Vaikų padaryti nužudymai ir sunkūs sveikatos sutrikdymai. Laboratorinè medicina. Mokslo darbai, 2013; 15, 2 (58): 78.

10. Campbell RJ. Psychiatric dictionary. Ed. R. J. Campbell. 7 th ed. New York, 1996; 798.

11. Daszkievicz K. Przestępstwa z afektu w polskim prawie karnom. Warszawa, 1982; 33.

12. Daškevičius K., Marcinkevičienè J. Nepakltinamumo klinikinès nozologinès ir kriminalinès struktūros analizè Lietuvoje (19852009 m.). Sveikatos mokslai, 2014; (1): 5-6. 
13. Dembinskas A. ir kt. Psichiatrija. Vilnius, 2003; 163, 672.

14. Dmitrijeva T., Safuanov F. Kriteriji ograničenoj sposobnosti k osoznaniju i reguliaciji kriminalno-agresivnych dejstvij obviniajemych. Rosijskaja psichiatrija, 2001; (3): 50-53.

15. Gruodytė E., Palionienè N. Riboto pakaltinamumo sampratos problematika lyginamuoju aspektu. Globalizacijos iššūkiai baudžiamajai justicijai. Vilnius, 2014; 70.

16. Marcinkevičienė J. Pakaltinamų asmenų su psichikos sutrikimais visuomenei pavojingų veikų prevencija. In Agresija ir smurtas - psichiné norma ir patologija. Vilnius, 2001; 92.

17. Račkauskaitė J., Danilevičiūtė V., Navickas A. Haliucinacijų etiologijos aspektai. Sveikatos mokslai, 2014; (1):78-79.

18. Šostakovič B. Sudebno - psichiatričeskaja ekspertiza pri rastroistvach ličnosti. Rukovodstvo po psichiatrii. Maskva, 2004; 237-238.

19. Tkačenko V. Otvetstvenost za umyšlenyje prestuplenija protiv žizni i zdorovija, soveršonyje v sostojanii afekta. Maskva, 1979; 32.

20. Vaitkevičiūtė V. Tarptautinių žodžių žodynas. A - K. Vilnius, 1999; 46.

21. Waters F, Allen P., Aleman A., Fernuhough C., Woodward TS., Bakcock JC., Barkus E., Johns L., Varese F., Menom M ., Vercammen A., Laroi F. Auditory Hallucinations in Schizophrena and Nonschizophrenia Populations: A Review and Integrated Model of Cognitive Mechanisms. Schizophr Bull 2012; 38(4):688-690.

\section{Teismų praktika}

22. Lietuvos Aukščiausiojo Teismo baudžiamoji byla Nr. 2K105/2015.

23. Lietuvos Aukščiausiojo Teismo baudžiamoji byla Nr. 2K$189 / 2013$.

24. Lietuvos Aukščiausiojo Teismo baudžiamoji byla Nr. 2K266/2012.

25. Lietuvos apeliacinio teismo baudžiamoji byla Nr. 1A-20/2013.

26. Lietuvos apeliacinio teismo baudžiamoji byla Nr. 1A-30/2011.

27. Lietuvos apeliacinio teismo baudžiamoji byla Nr. 1A-273/2011.

28. Lietuvos apeliacinio teismo baudžiamoji byla Nr. 1A-278/2011.

29. Lietuvos apeliacinio teismo baudžiamoji byla Nr. 1A-478/2011.

30. Lietuvos apeliacinio teismo baudžiamoji byla Nr. 1A-325/2011.

31. Lietuvos apeliacinio teismo baudžiamoji byla Nr. 1A-336/2011.

32. Vilniaus apygardos teismo baudžiamoji byla Nr. M1-119$166 / 2015$.

33. Vilniaus apygardos teismo baudžiamoji byla Nr. M1-386$626 / 2014$.

34. Vilniaus apygardos teismo baudžiamoji byla Nr. M1-1-386$326 / 2014$.
35. Vilniaus apygardos teismo baudžiamoji byla Nr. M1-341$387 / 2013$.

36. Vilniaus apygardos teismo baudžiamoji byla Nr. 1-126/2010.

37. Vilniaus miesto apylinkès prokuratūros baudžiamoji byla $\mathrm{Nr}$. 14-1-2325-07.

\section{THE SIGNIFICANCE OF PHYSIOLOGICAL AFFECT FOR QUALIFICATION OF MURDER AND SEVERE HEALTH IMPAIRMENT}

\section{R. Aliukonienė, N. Aliukonienè, V. Aliukonis}

Key words: homicide, grievous bodily injury, illegal or highly offensive action of the victim, pathological and physiological affect, forensic psychiatric examination.

Summary

Based on the laws of Lithuania and all democratic states, human life and health are considered as the most important values as well as a unique condition and basis of all other human values. Protection of human life and health may be ensured by establishing standards of various legal fields as well as determining criminal liability for encroachment on human life and health. The Criminal Code of the Republic of Lithuania (hereinafter referred to as the $\mathrm{CC})$ determines liability for a simple or qualified homicide in Article 129, whereas grievous bodily injury is covered in Article 135. Moreover, the aforementioned criminal acts may be committed when the perpetrator is in the state of diminished responsibility (physiological affect), therefore the legislator considers such acts to be exclusive and establishes liability for homicide and grievous bodily injury in a highly agitated state in different regulations of the Code (Art. 130 and Art. 136 of the CC).

The issues of qualification and dissociation of homicide and grievous bodily injury in the state of affect are rather complicated in terms of the practical aspect there of not only for lawyers but for forensic psychiatrists as well because usually the mental state of the subject at the time of the crime is examined much later, i.e. the experts must provide conclusions about the mental state of the subject in the past.

Analysis of the material of 20 criminal cases done within the course of this research paper enables to draw a conclusion that there are only individual cases stating that the perpetrator committed a homicide and grievous bodily injury in a state caused by a physiological affect. The criminal acts under analysis are mostly committed by mentally sane individuals, whereas mental patients, i.e. insane people, get involved in them significantly less frequently.

Correspondence to: rita.aliukoniene@prokuraturos.lt

Gauta 2015-11-26 